\title{
QUANTITATIVE STUDIES ON EXCRETION OF POLIOMYELITIS VIRUS: A COMPARISON OF VIRUS CONCENTRATION IN THE STOOLS OF PARALYTIC AND NON-PARALYTIC PATIENTS ${ }^{1}$
}

\author{
BY ROBERT WARD, GERALD A. LOGRIPPO, IRVING GRAEF, AND \\ DAVID P. EARLE, JR. \\ (From the Departments of Pediatrics and Medicine, New York University College of Medicine, \\ New York, N. Y.)
}

(Submitted for publication August 6, 1953; accepted November 25, 1953)

During the course of another study (1) it was necessary to determine the concentration of poliomyelitis virus excreted in the feces of patients. Stool specimens were obtained from two groups of patients designated for the present as Groups I and II. The purpose of this paper is to report observations on the titer of virus found in the stools of patients with poliomyelitis. The titer was generally higher in paralytic patients as compared to nonparalytics and to patients with mild transitory weakness. Certain differences in the composition of the two groups of patients and in the handling of the stools from each group became apparent after the titrations were done and will be discussed.

\section{MATERIAL AND METHODS}

Material for this study was obtained from patients with poliomyelitis admitted to Willard Parker ${ }^{2}$ and to Bellevue Hospitals ${ }^{2}$ in their first week of illness during the 1949 epidemic in New York City. The age of the patients varied from 6 months to 22 years (Table I).

The first stool specimen (A) was obtained during the first week of illness, and a second specimen (B) was collected 7 days later. They were stored in the solid state $\left(-30^{\circ}\right.$ C. $)$ until prepared for inoculation.

Preparation of stool for inoculation. The stool was thawed and mixed in a Waring Blendor with sterile distilled water to make a 10 per cent suspension. The suspension was centrifuged at 4000 r.p.m. for 30 minutes at $4^{\circ} \mathrm{C}$. (International Centrifuge PR1, angle head). The supernatant fluid was removed and shaken briefly with one-fourth to one-half volume of reagent ether, and stored overnight at $2^{\circ} \mathrm{C}$. The next morning, after removal of the ether, the suspension was centrifuged again as described above. The middle aqueous layer was pipetted off and centrifuged at 18,000 r.p.m. for 1 hour at $4^{\circ}$ C. (International, PR1, angle head). To the final supernatant fluid penicillin 1000 units per $\mathrm{ml}$. and streptomycin $10 \mathrm{mg}$.

1 Aided by a grant from the National Foundation for Infantile Paralysis, Inc.

2 We thank the Medical and Nursing staffs of Willard Parker Hospital and Bellevue Hospital for their help in collecting material. per ml. were added. Portions of the material were cultured on a blood agar plate and inoculated into monkeys. Aliquots were stored at $-30^{\circ} \mathrm{C}$.

Inoculation of monkeys. Immature rhesus monkeys (macaca mulatta) weighing usually 5 to 7 pounds were each given $1 \mathrm{ml}$. of stool suspension by the intracerebral route under ether anesthesia. They were examined daily for 28 days. At that time, if no signs of poliomyelitis had appeared, they were sacrificed and the spinal cord and medulla examined histologically. Monkeys exhibiting microscopic lesions typical of poliomyelitis were counted as positive. The diagnosis in animals which had developed weakness or paralysis during the observation period was confirmed also by microscopic examination of the spinal cord.

Titration in monkeys. The 10 per cent suspension of stool was first inoculated into a group of six monkeys as described above. If none developed poliomyelitis, the stool was considered negative. If one or more animals acquired the disease, an aliquot of this original suspension $\left(10^{-1}\right)$ was thawed and serial decimal dilutions in sterile distilled water were made through $10^{-8}$. Six monkeys were inoculated with each dilution which was prepared just prior to injection and held in an ice bath. If an end point was not achieved by this procedure additional dilutions of $10^{-6}$ or $10^{-6}$ were prepared from the original suspension and similarly inoculated.

Titration in tissue culture. Some of the stool suspensions were also titrated in tissue culture. The roller tube culture method described by Robbins, Weller, and Enders (2) was used with certain modifications (3-7). Monkey (rhesus or cynomolgus) testicular tissue provided the source of fibroblastic outgrowth. Eight to ten fragments were placed on the wall of each tube. Nutrient fluids of varied composition were used. The combination of Hanks-Simms medium and lactalbumin hydrolysate as described by Melnick and Riordan (8) proved to be satisfactory. After 6 or 7 days when the growth of fibroblasts was usually adequate, the nutrient fluid was removed from the tubes. Serial decimal dilutions of stool in fresh medium were prepared through the range $10^{-2}$ to $10^{-7}$. Of each dilution, $1 \mathrm{ml}$. was inoculated into each of three tubes. The tubes were rolled at 6 revolutions per hour at $35^{\circ} \mathrm{C}$. They were examined frequently during 8 to 10 days for the cytopathic changes first reported by Robbins, Enders, and Weller (9) as characteristic of poliomyelitis virus. Widespread granulation and destruction of fibroblasts 
TABLE I

Concentration of poliomyelitis virus in stools of two groups of patients determined by titration in monkeys

\begin{tabular}{|c|c|c|c|c|c|c|c|c|c|}
\hline \multicolumn{5}{|c|}{ Group I } & \multicolumn{5}{|c|}{ Group II } \\
\hline \multirow[b]{2}{*}{ Patient } & \multirow[b]{2}{*}{ Age } & \multicolumn{2}{|c|}{ Illness } & \multirow[b]{2}{*}{ Titert } & \multirow[b]{2}{*}{ Patient } & \multirow[b]{2}{*}{ Age } & \multicolumn{2}{|c|}{ Illness } & \multirow[b]{2}{*}{ Titer } \\
\hline & & Type* & $\overline{\text { Day of }}$ & & & & Type* & Day of & \\
\hline $\begin{array}{l}\text { Biv } \\
\text { Sap } \\
\text { Win } \\
\text { Mun } \\
\text { Mol } \\
\text { Kur } \\
\text { Mag } \\
\text { Moo } \\
\text { Kun } \\
\text { Nix } \\
\text { Mar } \\
\text { Lis }\end{array}$ & $\begin{array}{c}\text { (Years) } \\
5 \\
7 \\
6 \\
2 \\
8 \\
22 \\
7 \\
5 \\
15 \\
7 \\
8 \\
10\end{array}$ & $\begin{array}{l}\text { NP } \\
P \\
P \\
P \\
W k \\
W k \\
N P \\
W k \\
W k \\
P \\
\text { NP } \\
\text { NP }\end{array}$ & $\begin{array}{l}2 \\
4 \\
5 \\
4 \\
6 \\
5 \\
2 \\
4 \\
2 \\
3 \\
4 \\
5\end{array}$ & $\begin{array}{r}4,000 \\
500 \\
500 \\
400 \\
40 \\
30 \\
16 \\
16 \\
10 \\
5 \\
4 \\
4\end{array}$ & $\begin{array}{l}\text { Rom } \\
\text { Apo } \\
\text { Bra } \\
\text { Cav } \\
\text { DeA } \\
\text { Cas } \\
\text { Con } \\
\text { Bow } \\
\text { Sta }\end{array}$ & $\begin{array}{c}\text { (Years) } \\
1.5 \\
8 \\
7 \\
0.5 \\
1.5 \\
10 \\
12 \\
6 \\
11\end{array}$ & $\begin{array}{l}\mathrm{P} \\
\mathrm{P} \\
\mathrm{P} \\
\mathrm{P} \\
\mathrm{P} \\
\mathrm{P} \\
\mathrm{P} \\
\mathrm{NP} \\
\mathrm{Wk}\end{array}$ & $\begin{array}{l}3 \\
3 \\
3 \\
6 \\
5 \\
5 \\
3 \\
6 \\
5\end{array}$ & $\begin{array}{r}20,000 \\
16,000 \\
10,000 \\
4,000 \\
3,000 \\
2,000 \\
500 \\
4 \\
4\end{array}$ \\
\hline
\end{tabular}

* NP = non-paralytic $; \mathrm{P}=$ paralytic; $\mathrm{Wk}=$ mild transitory paralysis or weakness.

+ Titer is expressed as the reciprocal of the dilution of stool causing infection in $\mathbf{5 0}$ per cent of the animals (or culture tubes) inoculated. This figure indicates the number of infectious doses of virus per gram of stool.

(designated as 3 plus or more) was required as evidence of the effect of virus (6a). The 50 per cent end point of titrations performed in roller tubes and in monkeys was calculated by the method of Reed and Muench (10). The end point is expressed in the tables as the reciprocal of the dilution causing infection in 50 per cent of the animals or culture tubes inoculated and indicates the number of infectious doses of virus per gram of stool. The resulting titers in monkeys and in tissue culture tubes are thereby made comparable. Neutralization tests were carried out in tissue culture (6a) on 3 strains which proved to be Type 1 .

There were certain differences in storage time and in the technique of processing stools of the two groups; specimens in Group I were kept frozen for a shorter period, e.g., for a few weeks to 18 months, than those in Group II which were frozen for about 30 months. The stools of both groups were prepared and inoculated in the same laboratory by the same method but by different hands.

\section{RESULTS}

Table I shows the titer, as measured in monkeys, of poliomyelitis virus in the stools of patients in Group I compared with those in Group II. The majority $(8 / 12)$ in Group I yielded titers of less than 50 , whereas seven of the nine patients in Group II had titers of 500 or more. In casting about for an explanation of this difference, the possibility was raised of an inadvertent selection of patients. Their clinical records were therefore reexamined. It was discovered that Group I comprised four paralytic patients, four non-paralytic, and four with mild transitory paralysis or weakness. On the other hand the patients in Group II- those with higher titers-were almost all paralytic cases. Moreover, three of the four highest titers in Group I were obtained from paralytics, whereas the two lowest values in Group II were obtained from a non-paralytic and a patient with transitory weakness. This is shown to better advantage in Table II in which the cases are regrouped according to clinical manifestations. The criteria for clinical classification were as follows: Paralytic patients were those who had severe or moderately severe paralysis usually with residual damage persisting at the time of discharge or transfer. $\mathrm{Pa}$ tients considered to have mild transitory paralysis or weakness improved rapidly and were discharged

TABLE II *

Titer of poliomyelitis virus in stools of patients in first week of illness according to clinical manifestations

\begin{tabular}{|c|c|c|c|c|c|}
\hline \multicolumn{2}{|c|}{ Paralytic } & \multicolumn{2}{|c|}{$\begin{array}{l}\text { Mild transitory } \\
\text { weakness }\end{array}$} & \multicolumn{2}{|c|}{ Non-paralytic } \\
\hline Patient & Titer & Patient & Titer & Patient & Titer \\
\hline $\begin{array}{l}\text { Rom } \\
\text { Apo } \\
\text { Bra } \\
\text { Cav } \\
\text { DeA } \\
\text { Cas } \\
\text { Con } \\
\text { Sap } \\
\text { Win } \\
\text { Mun } \\
\text { Nix }\end{array}$ & $\begin{array}{r}20,000 \\
16,000 \\
10,000 \\
4,000 \\
3,000 \\
2,000 \\
500 \\
500 \\
500 \\
400 \\
5\end{array}$ & $\begin{array}{l}\text { Mol } \\
\text { Kur } \\
\text { Moo } \\
\text { Kun } \\
\text { Sta }\end{array}$ & $\begin{array}{r}40 \\
30 \\
16 \\
10 \\
4\end{array}$ & $\begin{array}{l}\text { Biv } \\
\text { Mag } \\
\text { Lis } \\
\text { Mar } \\
\text { Bow }\end{array}$ & $\begin{array}{r}4000 \\
16 \\
4 \\
4 \\
4\end{array}$ \\
\hline $\begin{array}{l}\text { Geometric } \\
\text { mean }\end{array}$ & 1308.0 & & 15.03 & & 21.01 \\
\hline
\end{tabular}

* Figures similar to those in Table I. 
in three to nine weeks without handicapping residual damage. Non-paralytic patients had characteristic spinal fluid changes but no detectable weakness at any time. Table II shows that the titers yielded by the A stools of paralytic patients were generally higher than those with less severe manifestations and vice versa. There was one exception in each group (patients $N i x$ and $B i v$ ).

As shown in Table II, the geometric mean of the titers of the paralytic group was 1308; of the mild transitory weakness group, 15 ; and of the nonparalytic group, 21. Analysis of the variance performed on the log titers showed a highly significant difference between these means ( $P$ only slightly greater than 0.001). Because the data do not fall into a normal distribution curve, the appropriateness of this analysis might be questioned. Therefore, a chi-square contingency test was applied. The cases in each of the three groups were classified as either above or below the median titer (400) of the 21 subjects. Chi-square was 13.20 which for 2 degrees of freedom yields a $P$ value again only slightly greater than 0.001 .

In spite of the small samples there can be no reasonable doubt that something more than chance was responsible for the differences. Since there is no adequate indication of a difference in titer between the non-paralytic patients and those with mild transitory weakness, the chief distinction is between the latter group and those classified as paralytic. When these two were compared, again

TABLE III *

Poliomyelitis virus in patients' stools titrated in monkeys and in tissue culture

\begin{tabular}{|c|c|c|c|c|}
\hline \multirow[b]{2}{*}{ Patient } & \multicolumn{2}{|c|}{ 1st week stool (A) } & \multicolumn{2}{|c|}{ 2nd week stool (B) } \\
\hline & Monkeyt & $\begin{array}{l}\text { Tissue } \\
\text { culturef }\end{array}$ & Monkey & $\begin{array}{l}\text { Tissue } \\
\text { culture }\end{array}$ \\
\hline Bra & 10,000 & 3,000 & 70 & 16,000 \\
\hline Biv & 4,000 & 30,000 & 5 & 1,000 \\
\hline Moo & 16 & $<10$ & 4 & 500 \\
\hline Rom & 20,000 & 16,000 & 300 & 30,000 \\
\hline Cav & 4,000 & 10,000 & 1,000 & 30,000 \\
\hline Con & 500 & 1,600 & 150 & 1,000 \\
\hline Apo & 16,000 & 10,000 & 250 & 1,000 \\
\hline DeA & 3,000 & 5,000 & 3,000 & 10,000 \\
\hline Win & 500 & 1,600 & 50 & 100 \\
\hline Cas & 2,000 & 3,000 & 4,000 & 1,600 \\
\hline Mun & 400 & 500 & & $<10$ \\
\hline
\end{tabular}

* Figures similar to those in Table I.

† Six monkeys inoculated intracerebrally with $1 \mathrm{ml}$. of each dilution.

$\ddagger$ Three roller tubes inoculated with $1 \mathrm{ml}$. of each dilution. with reference to the median, in a fourfold table by Fisher's "exact" method, the difference was found to be highly significant ( $P$ from Mainland's tables [11] being less than 0.01 ).

Some of the stools were titrated also in roller tube cultures of monkey testicular tissue (3-7). A comparison of results in tissue culture and in monkeys (Table III) shows good agreement for results in the first week, or A stools. On the other hand, four of the B specimens (Bra, Biv, Moo, Rom), obtained in the second week of illness, show a hundred-fold difference or more in favor of tissue culture; a smaller difference (approximately 10-fold) was found in two others (Cav and Con). In the remaining five there was little or no difference in titer.

\section{DISCUSSION}

The fact that stools have been shown in this study to yield titers of poliomyelitis virus as high as 20,000 is in itself of more than passing interest. There are few titrations of virus in stool reported in the literature. Pearson and Rendtorff mention the occurrence of paralysis in a monkey produced by a $10^{-5}$ dilution of stool excreted by a child with inapparent poliomyelitis (12). Melnick titrated two pools of feces from 11 patients in the first week of illness. One pool yielded a titer of 30 , the other 100 (13).

When an apparent difference in titer of virus was observed in our two groups of patients whose stools were collected in the same stage of illness in the same epidemic, a reinvestigation of clinical data pertaining to their illness was an important step in seeking an explanation. We discovered to our surprise that high titers were obtained for the most part from patients who had severe to moderately severe paralysis with residual damage. Conversely, less virus seemed to be excreted by non-paralytic patients and by those with mild transitory paralysis or weakness. Before speculating on its possible significance, it should be emphasized that this finding was an unexpected by-product of another investigation (1). As such it suffers from not being properly controlled in certain respects. For example, the stools of patients in Group I were kept frozen for a shorter period than those in Group II; although the stools of both were processed and inoculated into monkeys by the same method described above and in 
the same laboratory, the procedures were carried out in different years and by different hands. Although it has not been possible to retitrate in monkeys the stools of Group I to check the earlier results, titrations in tissue culture have been performed in four (Biv, Moo, Win, and Mun): Table III shows that the A stool titers achieved in tissue culture recently are not much different from those obtained in monkeys two to three years ago. Although it is difficult to see how the factors of storage and processing could explain the observed differences in titer between the paralytic and non-paralytic groups, until the work is repeated under conditions that are better controlled, we think that the findings should be interpreted with reserve.

A comparison of virus titers obtained in monkeys and in tissue culture showed an interesting difference in the second week (B) specimens. Although there was little or no difference in titers of the A stools done by the two different methods, a considerable difference was found in a number of the B stools. The titer in tissue culture was higher by 100 -fold or more than the titer in monkeys. The explanation of this is not clear. In any event, it suggests that if one is seeking variants of poliomyelitis virus with reduced pathogenicity for primates, stool passed after the first week of illness may offer a better source than earlier excretions.

\section{SUM MARY}

1. A quantitative study of poliomyelitis virus was carried out in stools obtained in the first and second weeks of illness of 21 patients during the 1949 poliomyelitis epidemic in New York City.

2. Virus in stool was titrated in monkeys and in roller tubes containing monkey testicular tissue.

3. High titers of virus, ranging from 2,000 to 20,000 , were obtained in one third of the patients' stools tested in monkeys.

4. Stools of the 11 paralytic patients generally yielded high titers; stools of five non-paralytics and of five patients with mild transitory paralysis or weakness generally yielded low titers of virus.

5. A comparison of values obtained by titration in monkeys and in tissue culture showed good agreement in the first week stools. Some of the second week stools, however, showed a lower pathogenicity for monkeys while exhibiting persistently high titers for tissue culture.

\section{REFERENCES}

1. Ward, R., LoGrippo, G. A., Earle, D. P., Jr., and Graef, I., Effect of a mercurial compound on excretion of poliomyelitis virus in patients' stools. Federation Proc., 1953, 12, 464.

2. Robbins, F. C., Weller, T. H., and Enders, J. F. Studies on the cultivation of poliomyelitis viruses in tissue culture. II. The propagation of the poliomyelitis viruses in roller-tube cultures of various human tissues. J. Immunol., 1952, 69, 673.

3. Smith, W. M., Chambers, V. C., and Evans, C. A., Growth of neurotropic viruses in extraneural tissues. IV. Poliomyelitis virus in human testicular tissue in vitro. Proc. Soc. Exper. Biol. \& Med., 1951, 76, 696.

4. Syverton, J. T., Scherer, W. F., and Butorac, G. Propagation of poliomyelitis virus in cultures of monkey and human testicular tissues. Proc. Soc. Exper. Biol. \& Med., 1951, 77, 23.

5. Ledinko, N., Riordan, J. T., and Melnick, J. L., Differences in cellular pathogenicity of two immunologically related poliomyelitis viruses as revealed in tissue culture. Proc. Soc. Exper. Biol. \& Med., 1951, 78, 83.

6a. Ledinko, N., Riordan, J. T., and Melnick, J. L., Multiplication of poliomyelitis viruses in tissue cultures of monkey testes. I. Growth curves of type 1 (Brunhilde) and type 2 (Lansing) strains and description of a quantitative neutralization test. Am. J. Hyg., 1952, 55, 323.

6b. Riordan, J. T., Ledinko, N., and Melnick, J. L., Multiplication of poliomyelitis viruses in tissue cultures of monkey testes. II. Direct isolation and typing of strains from human stools and spinal cords in roller tubes. Am. J. Hyg., 1952, 55, 339.

7. Youngner, J. S., Ward, E. N., and Salk, J. E., Studies on poliomyelitis viruses in cultures of monkey testicular tissue. I. Propagation of virus in roller tubes. Am. J. Hyg., 1952, 55, 291.

8. Melnick, J. L., and Riordan, J. T., Poliomyelitis viruses in tissue culture. IV. Protein-free nutrient media in stationary and roller tube cultures. Proc. Soc. Exper. Biol. \& Med., 1952, 81, 208.

9. Robbins, F. C., Enders, J. F., and Weller, T. H., Cytopathogenic effect of poliomyelitis viruses in vitro on human embryonic tissues. Proc. Soc. Exper. Biol. \& Med., 1950, 75, 370.

10. Reed, L. J., and Muench, H., A simple method of estimating fifty per cent end points. Am. J. Hyg., 1938, 27, 493.

11. Mainland, D., Statistical methods in medical research. I. Qualitative statistics (enumeration data). Canad. J. Research., Section E. Medical Sciences, 1948, 26, 1.

12. Pearson, H. E., and Rendtorff, R. C., Studies of the distribution of poliomyelitis virus. II. In a small town. Am. J. Hyg., 1945, 41, 179.

13. Melnick, J. L., Poliomyelitis virus in urban sewage in epidemic and in non-epidemic times Am. J. Hyg., $1947,45,240$. 